\title{
Self-efficacy in first-year university students: a descriptive study
}

\author{
Paula Álvarez-Huerta ${ }^{1}$, Iñaki Larrea ${ }^{1}$, Alexander Muela ${ }^{2}$, Jose Ramón Vitoria ${ }^{1}$ \\ ${ }^{1}$ Innovation and Intervention in Inclusive Education, Mondragon University, Spain, \\ ${ }^{2}$ Department of Personality, Assessment and Psychological Treatment, University of the \\ Basque Country UPV/EHU, Spain.
}

\begin{abstract}
The study and analysis of the self-efficacy beliefs of students has become an important line of educational research. The purpose of this study, conducted at Mondragon University (Spain), is to explore the different perceptions concerning the creative and entrepreneurial self-efficacy of students on their entrance to university. Results revealed clear patterns with regards to discipline and gender. Students commencing their degrees in social sciences show lower creative and entrepreneurial self-efficacy perceptions than their peers in other disciplines. Women show lower scores than men across different disciplines with the exception of women commencing engineering studies.
\end{abstract}

Self-efficacy has been related to student motivation and learning and has been found influential in the choice of the professional career. The high significance of this construct in education makes the results of this study have clear implications for the development of learning environments that address the differences found between gender and disciplines. Directions for future research are also indicated.

Keywords: Self-efficacy; university students; gender; creativity; entrepreneurship. 


\section{Introduction}

Self-efficacy, the confidence people have in their ability to do certain tasks (Jordan \& Carden, 2017), has become an important line of investigation in educational research. Several studies have revealed the key role self-efficacy plays in student performance and learning by means of affecting the tasks chosen by them, their effort, perseverance and performance (Schunk, 2003). The role of the self-efficacy construct as mediator and predictor of student performance, motivation and learning has been also identified in higher education (Van Dinther, Dochy, \& Segers, 2011). This study will analyse the self-efficacy perceptions, with regards to creativity and entrepreneurship, of a cohort of students as they commence their university experience. The development of creative and entrepreneurial skills, an explicit learning outcome of the institution in which this study has been developed, has become a significant subject of study in higher education (Daly, Mosyjowski, \& Seifert, 2016; Newman, Obschonka, Schwarz, Cohen, \& Nielsen, 2018).

Self-efficacy consists of an individual's confidence in his or her ability to effectively engage in behaviours towards desired goals (Bandura, 1997). There is increasing attention given to this construct in educational research (Van Dinther et al., 2011) and studies have confirmed the relationship between student self-efficacy and academic achievement (Bowman, Miller, Woosley, Maxwell, \& Kolze, 2019).

Entrepreneurial self-efficacy (ESE) refers to an individual's confidence in his or her competence to perform entrepreneurial tasks and roles (Chen, Greene, \& Crick, 1998). The relation between entrepreneurial self-efficacy and the entrepreneurial career has been analysed and clear patterns emerge: those with greater self-efficacy in this field show greater entrepreneurial intentions and greater confidence in the development of viable entrepreneurial ideas (Krueger, Reilly, \& Carsrud, 2000; Segal, Borgia, \& Schoenfeld, 2002). Other research shows the relationship between high entrepreneurial self-efficacy and behaviours related to entrepreneurship (Dempsey \& Jennings, 2014; Hmieleski \& Corbett, 2007).

Creative self-efficacy (CSE) has been defined as the confidence in one's ability to produce creative results (Tierney \& Farmer, 2002). This relatively recent field, has revealed significant associations between creative self-efficacy and creativity outcomes in education and in other contexts (Beghetto, 2006; Farmer \& Tierney, 2017; Jaussi, Randel, \& Dionne, 2007; Shin \& Zhou, 2007).

Self-efficacy research has consistently shown the predictive nature of students' self-efficacy beliefs in career entry behaviours, such as university degree choices and academic performance (Lent \& Hackett, 1987; Markman, Balkin, \& Baron, 2002). 
The relationship between gender and self-efficacy has long been a focus of research. Wilson, Kickul and Marlino (2007) have found gender differences in entrepreneurial selfefficacy at the student level, with women having less confidence, on average, about their entrepreneurial capacity in relation to men. In addition, as suggested by Bandura, Barbaranelli, Caprara and Pastorelli ( 2001) women may be more strongly influenced than men by perceptions of lower skill in entrepreneurship.

Regarding creative self-efficacy and gender, the studies have showed weak differences, with men showing higher CSE scores and overestimating their creativity and women underestimating it (Beghetto, 2006; Karwowski, 2011; Karwowski, Lebuda, Wisniewska, \& Gralewski, 2013).

To our knowledge, and despite the vast literature on entrepreneurial and creative selfefficacy, there have been no studies analysing the different creative and entrepreneurial self-perceptions of students on entrance to different university disciplines, the focus of this study.

\section{Methods}

The study involved all full-time students newly enrolled in the first year of Mondragon University, a private university located in the Basque Country (Spain). The four different Faculties of Mondragon University took part in the study; 89 students of the Faculty of Gastronomic Sciences, 177 students of the Faculty of Business Studies, 225 students of the Faculty of Humanities and Social Sciences and 301 students of the Faculty of Engineering participated in this study. Forty-four percent of the respondents were female $\left(M_{\text {age }}=18.22\right.$, $S D=1.58)$, fifty-five percent male $\left(M_{\text {age }}=18.55, S D=2.45\right)$. The 710 students $\left(M_{\text {age }}=\right.$ $18.40, S D=2.11$ ) completed the entire questionnaire during class time.

The researchers were in charge of explaining the nature of the research, the access to the questionnaire and the procedures, as well as the privacy of the data.

Following the process of translation-back translation commonly used in research, the scales related to self-efficacy were translated independently from English into Basque and Spanish, to be later translated into English by two bilingual people and reviewed by the research team (Brislin, 1980).

Instruments. Creative self perceptions was assessed with Tierney and Farmer's creative self-efficacy measure (Tierney \& Farmer, 2002). A sample item from this scale is: "I have confidence in my ability to solve problems creatively."

We used the four-item scale of Zhao et al. (Zhao, Hills, \& Seibert, 2005) for assessing entrepreneurial self-efficacy. This scale measures the confidence of a person with respect to 
the identification of business opportunities, creation of new products, creative thinking, and commercialization of ideas (Bullough, Renko, \& Myatt, 2014).

\section{Results}

Table 1 displays means and standards deviations resulting from the sum of the corresponding items among the variables of interest. For the general sample, it was found that women had significantly both lower entrepreneurial and creative self-efficacy scores than men.

Table 1. Descriptive statistics

\begin{tabular}{|c|c|c|c|c|c|}
\hline & Gender & Faculty & Mean & SD & $\mathbf{N}$ \\
\hline \multirow[t]{10}{*}{ CSE } & \multirow[t]{5}{*}{ Women } & Business Studies & 15,72 & 2,06 & 85 \\
\hline & & Humanities and Educational Sciences & 14,99 & 1,72 & 122 \\
\hline & & Gastronomy & 15,57 & 1,72 & 30 \\
\hline & & Engineering & 15,70 & 1,80 & 82 \\
\hline & & Total & 15,42 & 1,86 & 319 \\
\hline & \multirow[t]{5}{*}{ Men } & Business Studies & 16,12 & 2,16 & 66 \\
\hline & & Humanities and Educational Sciences & 15,30 & 1,81 & 86 \\
\hline & & Gastronomy & 15,77 & 2,81 & 52 \\
\hline & & Engineering & 15,75 & 1,77 & 187 \\
\hline & & Total & 15,72 & 2,02 & 391 \\
\hline \multirow[t]{10}{*}{ ESE } & \multirow[t]{5}{*}{ Women } & Business Studies & 14,99 & 2,25 & 85 \\
\hline & & Humanities and Educational Sciences & 13,21 & 2,95 & 122 \\
\hline & & Gastronomy & 14,80 & 2,26 & 30 \\
\hline & & Engineering & 15,22 & 2,01 & 82 \\
\hline & & Total & 14,35 & 2,64 & 319 \\
\hline & \multirow[t]{5}{*}{ Men } & Business Studies & 15,29 & 2,17 & 66 \\
\hline & & Humanities and Educational Sciences & 13,83 & 2,35 & 86 \\
\hline & & Gastronomy & 15,71 & 2,20 & 52 \\
\hline & & Engineering & 14,87 & 2,02 & 187 \\
\hline & & Total & 14,82 & 2,22 & 391 \\
\hline
\end{tabular}


However, as Table 1 shows, these differences depend on the discipline of study. Students initiating their studies in the Faculty of Engineering show a distinct self-efficacy pattern. Women in the Faculty of Engineering have similar CSE scores to men and higher ESE scores than men. An interesting parallel finding from this study is that students initiating their degrees in different disciplines present different self-efficacy patterns. As seen in Table 1, students commencing studies in the Faculty of Humanities and Educational Sciences show lower ESE and CSE scores than their university peers.

\section{Discussion}

The present study reveals differences regarding self-efficacy perceptions of men and women. Some researchers argue that these differences may have their origin in the stereotypical beliefs about gender that students have (Eisenberg, Martin, \& Fabes, 1996; Harter, Waters, \& Whitesell, 1997). These divergences are highly relevant because of their predictive role in future professional choices (Bandura et al., 2001). The corroboration of the gender differences that exist in this educational stage is an opportunity to address problems that can contribute to continuing the persistent gender disparity in the professional career.

Interestingly, women commencing their studies in the Faculty of Engineering show a distinct entry profile, these women commencing degrees in which they traditionally represent a minority (30\% in our study) show a differentiated profile to their peers from other disciplines, Given the consideration of self-efficacy expectations as a mediator in career decisions (Ancis \& Phillips, 1996; Bandura et al., 2001), this finding seems to document the relation between perceived occupational efficacy and career choice found in the literature (Betz \& Hackett, 1983).

Another finding from the study is the lower self-efficacy perceptions, both creative and entrepreneurial, found in those students commencing their studies in social sciences disciplines._If, as the literature shows, perceptions of self-efficacy are decisive in the choice of the professional career (Lent \& Hackett, 1987) a possible explanation for this lower selfefficacy could be that neither creativity nor entrepreneurship are perceived by this cohort of students as essential skills in humanities and educational science degrees.

However, both creative and entrepreneurial skills are distinctive features of a mindset that can prepare students to develop in a future characterised by change. The development of entrepreneurial self-efficacy is a valid objective in itself in higher education institutions, due to its recognised predictive role in the development of not only entrepreneurial intentions but also entrepreneurial behaviours (Krueger \& Deborah Brazeal, 1994; Zhao, Hills, \& Seibert, 2005). Regarding creativity, higher levels of creative self-efficacy have been related, not only to greater creative performance, but also to greater confidence in 
academic skills and greater educational projection (Beghetto, 2006; Robbins \& Kegley, 2010; Tierney \& Farmer, 2004).

With regards to the research limitations, the study was limited to Mondragon University and therefore generalisability of the findings might be limited to this context. Additional quantitative and qualitative research is necessary to explore the external validity of the presented findings with regard to other countries, universities, and disciplines.

Furthermore, in the literature, concerns are raised about the use of one's perceptions, as they are potentially prone to biases and inaccuracies, and can cause problems when used as indicators of skills (Dunning, Heath, \& Suls, 2004). However, this may not apply when what is required is a subjective assessment of the skill. In constrast it is worth noting that making an assessment of subjective capacity may be a step towards developing creative potential (Beghetto, 2007).

Undergraduate years are seen as a critical opportunity for students, representing the moment in which their confidence in their own skills is built and choices are made about future professional career (Moss-Racusin, Dovidio, Brescoll, Graham, \& Handelsman, 2012). The significance of this educational stage and the malleable nature of the selfefficacy construct may support the design of educational interventions based on the selfefficacy development sources contemplated within social cognitive theory. In the view of the present study, these interventions should be directed at reducing the existing gender gap and changing pre-existing mental frameworks regarding the characteristics of professional profiles in different disciplines.

Future research could analyse the development of the self-efficacy perceptions of this cohort of students as they continue their university experience. The study of the environmental factors contributing to higher creative and entrepreneurial self-efficacy scores across genders and disciplines would provide valuable information, of particular interest to those researchers working in higher educational settings.

\section{References}

Bandura, A. (1997). Self-efficacy: the exercise of control. New York: W.H. Freeman and Company.

Bandura, A., Barbaranelli, C., Caprara, G. V., \& Pastorelli, C. (2001). Self-Efficacy Beliefs as Shapers of Children's Aspirations and Career. Child Development, 72(1), 187-206.

Baum, J. R., Locke, E. A., \& Smith, K. G. (2001). A multi-dimensional model of venture growth. Academy of Management Journal, 44(2), 292-303. Retrieved from http://citeseerx.ist.psu.edu/viewdoc/download?doi=10.1.1.507.739\&rep=rep1\&type=pdf

Baumol, W. J. (2005). Education for Innovation: Entrepreneurial Breakthroughs vs. Corporate Incremental Improvements. Innovation Policy and the Economy, 5, 33-56. Retrieved from www.pg.com, 
Beghetto, R. A. (2006). Creative self-efficacy: Correlates in middle and secondary students. Creativity Research Journal, 18(4), 447-457. https://doi.org/10.1207/s15326934crj1804_4

Beghetto, R. A. (2007). Factors Associated with Moddle and Secondary Students' Perceived Science Competence. Journal of Research in Science Teaching, 44(6), 800 814. https://doi.org/10.1002/tea

Bowman, N. A., Miller, A., Woosley, S., Maxwell, N. P., \& Kolze, M. J. (2019). Understanding the Link Between Noncognitive Attributes and College Retention. Research in Higher Education, 60(2), 135-152. https://doi.org/10.1007/s11162-0189508-0

Brislin, R. W. (1980). Cross-cultural research methods. In I. Altman, A. Rapoport, \& J. F. Wohlwill (Eds.), Environment and Culture. Human Behavior and Environment (Advances in Theory and Research) (pp. 47-82). Boston, MA: Springer US.

Bullough, A., Renko, M., \& Myatt, T. (2014). Danger zone entrepreneurs: The importance of resilience and self-efficacy for entrepreneurial intentions. Entrepreneurship: Theory and Practice, 38(3), 473-499. https://doi.org/10.1111/etap.12006

Chen, C. C., Greene, P. G., \& Crick, A. (1998). Does entrepreneurial self-efficacy distinguish entrepreneurs from managers? Journal of Business Venturing, 13(4), 295316.

Daly, S. R., Mosyjowski, E. A., \& Seifert, C. M. (2016). Teaching Creative Process across Disciplines. The Journal of Creativity Behavior, O(0), 1-13. https://doi.org/10.1002/jocb.158

Dempsey, D., \& Jennings, J. (2014). Gender and entrepreneurial self-efficacy: A learning perspective. International Journal of Gender and Entrepreneurship, 6(1), 28-49. https://doi.org/10.1108/IJGE-02-2013-0013

Dunning, D., Heath, C., \& Suls, J. M. (2004). Flawed Self-Assessment Implications for Health, Education, and the Workplace. Psychological Science in the Public Interest, 5(3), $69 . \quad$ Retrieved from http://citeseerx.ist.psu.edu/viewdoc/download?doi=10.1.1.1022.3431\&rep=rep1\&type= pdf

Farmer, S. M., \& Tierney, P. (2017). Considering Creative Self-Efficacy: Its Current State and Ideas for Future Inquiry. The Creative Self: Effect of Beliefs, Self-Efficacy, Mindset, and Identity, (November), 23-47. https://doi.org/10.1016/B978-0-12-809790-8.00002-9

Hmieleski, K. M., \& Corbett, A. C. (2007). The contrasting interaction effects of improvisational behavior with entrepreneurial self-efficacy on new venture performance and entrepreneur work satisfaction. https://doi.org/10.1016/j.jbusvent.2007.04.002

Jaussi, K. S., Randel, A. E., \& Dionne, S. D. (2007). I am, I think I can, and I do: The role of personal identity, self-efficacy, and cross-application of experiences in creativity at work. Creativity Research Journal, 19(2-3), 247-258. https://doi.org/10.1080/10400410701397339

Jordan, K., \& Carden, R. (2017). Self-efficacy and gender in STEM majors. Modern Psychological Studies, 22(2), 2017. Retrieved from https://scholar.utc.edu/cgi/viewcontent.cgi? article=1275\&context=mps 
Karwowski, M. (2011). It Doesn't Hurt to Ask... But Sometimes It Hurts to Believe: Polish Students' Creative Self-Efficacy and Its Predictors. Psychology of Aesthetics, Creativity, and the Arts, 5(2), 154-164. https://doi.org/10.1037/a0021427

Karwowski, M., Lebuda, I., Wisniewska, E., \& Gralewski, J. (2013). Big five personality traits as the predictors of creative self-efficacy and creative personal identity: Does gender matter? Journal of Creative Behavior, 47(3), 215-232. https://doi.org/10.1002/jocb.32

Krueger, N. F., Reilly, M. D., \& Carsrud, A. L. (2000). Competing models of entrepreneurial intentions. Journal of Business Venturing, 15, 411-432.

Lent, R. W., \& Hackett, G. (1987). Career self-efficacy: Empirical status and future directions. Article in Journal of Vocational Behavior, 30, 347-382. https://doi.org/10.1016/0001-8791(87)90010-8

Markman, G. D., Balkin, D. B., \& Baron, R. A. (2002). Inventors and New Venture Formation: the Effects of General Self-Efficacy and Regretful Thinking. Entrepreneurship Theory and Practice, 27(2), 149-165. Retrieved from https://www.effectuation.org/wp-content/uploads/2017/06/Markman_et_al-2002Entrepreneurship_Theory_and_Practice-1.pdf

Newman, A., Obschonka, M., Schwarz, S., Cohen, M., \& Nielsen, I. (2018). Entrepreneurial self-efficacy: A systematic review of the literature on its antecedents and outcomes, and an agenda for future research. Journal of Vocational Behavior, (October 2017), 1-17. https://doi.org/10.1016/j.jvb.2018.05.012

Schunk, D. H. (2003). Self-efficacy for reading and writing: Influence of modeling, goal setting, and self-evaluation. Reading and Writing Quarterly, 19, 159-172. Retrieved from http://www.psy.cmu.edu/ siegler/418-Schunk.pdf

Segal, G., Borgia, D., \& Schoenfeld, J. (2002). Using Social Cognitive Career Theory to Predict Self-Employment Goals. New England Journal of Entrepreneurship, 5(2), 4756. https://doi.org/10.1108/NEJE-05-02-2002-B007

Shin, S. J., \& Zhou, J. (2007). When Is Educational Specialization Heterogeneity Related to Creativity in Research and Development Teams? Transformational Leadership as a Moderator. Journal of Applied Psychology, 92(6), 1709-1721. https://doi.org/10.1037/0021-9010.92.6.1709

Tierney, P., \& Farmer, S. M. (2002). Self-efficacy: Its potential antecedents and relationship to creative performance. Academy of Management Journal, 45(6), 1137 1148.

Van Dinther, M., Dochy, F., \& Segers, M. (2011). Factors affecting students's self-efficacy in higher education. Educational Research Review, 6(2), 95-108. https://doi.org/10.1016/j.edurev.2010.10.003

Wilson, F., Kickul, J., \& Marlino, D. (2007). Gender, Entrepreneurial Self-Efficacy, and Entrepreneurial Career Intentions: Implications for Entrepreneurship Education. Education, 31(3), 387-406.

Zhao, H., Hills, G. E., \& Seibert, S. E. (2005). The mediating role of self-efficacy in the development of entrepreneurial intentions. Journal of Applied Psychology, 90(6), 12651272. https://doi.org/10.1037/0021-9010.90.6.1265 